\title{
1. Introduction: establishing copyright principles for an access world
}

The sustainability of copyright markets, and copyright itself, is increasingly driven by access. In this environment, the right of copyright owners to make their content available to the public occupies a central role. Despite its genesis in the World Intellectual Property Organization (WIPO) Internet Treaties of 1996, for most countries around the world, there is little consensus as to what this 'making available' right means. National and regional courts are using disparate approaches and terminology to interpret this broadly worded right. As a result, we are left with what seems to be an ad hoc, fact-specific right that fails to instil confidence in our contemporary copyright system.

Despite the inconsistencies on the face of these decisions, underlying themes may be found. This book brings these themes to the surface and reveals the foundational shift brought about by these decisions - a necessary step before we can plot a principled way forward. In doing so, it suggests that copyright has an underserved dissemination function, which can be developed and nurtured through a principled interpretation of the making available right. At its core, this book addresses the need to bring transparency to the decision-making processes behind the development of the making available right. It is the key right in the digital age and an important driver of content dissemination markets, and we cannot continue to take it for granted.

\subsection{LIMITED ENGAGEMENT WITH THE MAKING AVAILABLE RIGHT}

The making available right, stated in the WIPO Copyright Treaty (WCT) as a sub-right to the communication right, provides that:

authors of literary and artistic works shall enjoy the exclusive right of authorizing any communication to the public of their works, by wire or wireless means, including the making available to the public of their works in such a way that members of 
the public may access these works from a place and at a time individually chosen by them. ${ }^{1}$

The increasing importance of the making available right in today's communications environment cannot be understated. Digital technologies and the online access markets developing around them are swiftly displacing the traditional reliance on the distribution of multiple copies of copyright works for income generation. ${ }^{2}$ Consumers, as described by the Director-General of WIPO, Dr Francis Gurry, have an interest in 'the short-term gratification of immediate consumption' ${ }^{3}$ - something which no longer requires the distribution of copies. In these online markets, value lies primarily in access to the work that is, experiencing a transient representation of the work without necessarily acquiring a tangible copy. ${ }^{4}$

1 WIPO Copyright Treaty, signed 20 December 1996, S Treaty Doc No 105-17 (1997); 36 ILM 65 (1997) (entered into force 6 March 2002) art 8 ('WCT') (Australia entry into force 26 July 2007; US entry into force 6 March 2002; EU entry into force 14 March 2010). The WIPO Performances and Phonograms Treaty provides that performers and phonogram producers hold the making available right as a standalone right in relation to their respective fixed performances/phonograms: WIPO Performances and Phonograms Treaty, signed 20 December 1996, S Treaty Doc No 105-17, 36 ILM 76 (1997) (entered into force 20 May 2002), arts 10 and 14 ('WPPT') (Australia entry into force 26 July 2007; US entry into force 20 May 2002; EU entry into force 14 March 2010).

2 See William A van Caenegem, 'Copyright, Communication and New Technologies’ (1995) 23 Federal Law Review 322, 325.

3 This interest was raised in the context of discussing the central question of copyright policy. Dr Gurry stated:

How can society make cultural works available to the widest possible public at affordable prices while, at the same time, assuring a dignified economic existence to creators and performers and the business associates that help them navigate the economic system? It is a question that implies a series of balances: between availability, on the one hand, and control of the distribution of works as a means of extracting value, on the other hand; between consumers and producers; between the interests of society and those of the individual creator; and between the short-term gratification of immediate consumption and the long-term process of providing economic incentives that reward creativity and foster a dynamic culture.

Francis Gurry, 'The Future of Copyright' (at the Blue Sky Conference: Future Directions in Copyright Law, Sydney, 25 February 2011) $<$ http://www.wipo.int/about -wipo/en/dgo/speeches/dg_blueskyconf_11.html>, accessed 26 October 2015; Francis Gurry, 'Foreword: The Future of Copyright' in Brian Fitzgerald and John Gilchrist (eds), Copyright Perspectives: Past, Present and Prospect (Springer, 2015) vi.

${ }_{4}$ See Jane C Ginsburg, 'From Having Copies to Experiencing Works: The Development of an Access Right in U.S. Copyright Law' in Hugh Hansen (ed), US Intellectual Property Law and Policy (Edward Elgar, 2000) 39; Guido Westkamp, 
The making available right was conceived as part of a suite of reforms under the WIPO Digital Agenda, which served to set out 'the work program and objectives of WIPO with respect to electronic commerce, the digital economy and intellectual property'. ${ }^{5}$ The WCT and WIPO Performances and Phonograms Treaty (WPPT), collectively known as the 'Internet Treaties', established this broad making available right to address on-demand transmissions of copyright works and other subject matter through interactive systems. This meant the coverage of not just 'push' technologies, but also 'pull' technologies. ${ }^{7}$ The aim was to fill the gaps left by the technology-centric rights of copyright's foundational international treaty, the Berne Convention for the Protection of Literary and Artistic Works, ${ }^{8}$ which covered online communications incompletely and imperfectly. ${ }^{9}$ This new making available right was revolutionary at the time, as it would be irrelevant whether copies of a work were made available or whether the work was simply 'made perceptible' to users. ${ }^{10}$ The concept of making available would extend to acts which make

'Transient Copying and Public Communications: The Creeping Evolution of Use and Access Rights in European Copyright Law' (2004) 36(5) George Washington International Law Review 1057.

$5 \quad$ World Intellectual Property Organization, 'WIPO Digital Agenda: Memorandum of the Director General' (24th Session, WIPO General Assembly, WO/GA/24/11, 22 September 1999).

6 Mihály Ficsor, The Law of Copyright and the Internet: The 1996 WIPO Treaties, Their Interpretation and Implementation (Oxford University Press, 2002) 414-15.

7 WIPO, 'Basic Proposal for the Substantive Provisions of the Treaty on Certain Questions Concerning the Protection of Literary and Artistic Works to Be Considered by the Diplomatic Conference (on Certain Copyright and Neighboring Rights Questions, Geneva, 2-20 December 1996), WIPO Doc CRNR/DC/4 (30 August 1996)' 44, $<$ http://www.wipo.int/meetings/en/doc_details.jsp?doc_id=2481>, accessed 2 August 2017 ('Basic Proposal for Draft Treaty No. 1').

8 Berne Convention for the Protection of Literary and Artistic Works, signed 9 September 1886, (entered into force 5 December 1887) ('Berne Convention'), as amended on 28 September 1979, WIPO Lex No TRT/BERNE/001 (entered into force 19 November 1984).

9 Jane C Ginsburg, 'The (New?) Right of Making Available to the Public' in David Vaver and Lionel Bently (eds), Property in the New Millenium: Essays in Honour of William R. Cornish (Cambridge University Press, 2004) 234-47. See also International Bureau of WIPO, 'The WIPO Copyright Treaty (WCT) and the WIPO Performances and Phonograms Treaty (WPPT)' <http://www.wipo.int/export/sites/ www/copyright/en/activities/pdf/wct_wppt.pdf>, accessed 14 November 2017; Mihály Ficsor, 'Towards a Global Solution: The Digital Agenda of the Berne Protocol and the New Instrument: The Rorschach Test of Digital Transmissions' in P Bernt Hugenholtz (ed), The Future of Copyright in a Digital Environment (Kluwer, 1996) 111-21.

${ }_{10}$ WIPO, Summary Minutes, Main Committee I (WIPO Diplomatic Conference on Certain Copyright and Neighboring Rights Questions, Geneva, 2-20 December 1996), WIPO Doc CRNR/DC/102 ('Summary Minutes') $40<$ http://www.wipo.int/meetings/ 
the work accessible by the public, even if 'members of the public still have to cause the system to make it actually available to them' ${ }^{11}$

The WIPO Internet Treaties were concluded in Geneva on 20 December 1996. ${ }^{12}$ The advancements in online communications that have proliferated since then mean that the convenience of ubiquitous and seamless access sought by consumers of content and information is now possible. This world of access presents a new paradigm - rather than controlling copies, copyright owners now seek to control various means of access. ${ }^{13}$ In this environment, the making available right will occupy a central role in regulating such copyright markets. Unfortunately, courts have yet to develop a principled and considered approach that addresses this basal shift in how copyright content is disseminated to the public. There remains little agreement on the scope of this right, more than two decades since it was introduced. We have but a vague idea of what conduct ought to fall within the scope of the right, and courts around the world have faced challenges when applying the right to individualized communications online.

The lack of engagement with the making available right is apparent on the face of contemporary decisions. Despite significant changes in the way that content is disseminated today, copyright law analysis still often centres on the

en/doc_details.jsp?doc_id=2472>, accessed 11 July 2015 (Chairman Jukka Liedes's opening remarks on Article 10 of the WCT).

${ }_{11}$ WIPO, 'Guide to the Copyright and Related Rights Treaties Administered by WIPO and Glossary of Copyright and Related Rights Terms (CT-8.6)' (2003) 208 $<$ http://www.wipo.int/edocs/pubdocs/en/copyright/891/wipo_pub_891.pdf>, accessed 8 July 2015. See also Ficsor, above n 6, 131.

$12 W C T$, signed 20 December 1996, S Treaty Doc No 105-17 (1997); 36 ILM 65 (1997) (entered into force 6 March 2002) Article 8; WPPT, signed 20 December 1996, S Treaty Doc No 105-17, 36 ILM 76 (1997) (entered into force 20 May 2002) articles 10 and 14. The Internet Treaties entered into force in 2002 and have since been acceded to or ratified by 102 contracting parties: see WIPO, WIPO-Administered Treaties: Contracting Parties - WIPO Copyright Treaty <http://www.wipo.int/ treaties/en/ShowResults.jsp?lang=en\&treaty_id=16> accessed 23 May 2019; WIPO, WIPO-Administered Treaties: Contracting Parties - WIPO Performances and Phonograms Treaty <http://www.wipo.int/treaties/en/ShowResults.jsp?lang=en\& treaty_id=20>, accessed 23 May 2019.

${ }_{13}$ Cf Brian Fitzgerald, 'Copyright in the Age of Access' in John Gilchrist and Brian Fitzgerald (eds), Copyright, Property and the Social Contract: The Reconceptualisation of Copyright (Springer International, 2018) 183. 
exclusive reproduction right. ${ }^{14}$ Cases involving the provision of cloud-based ${ }^{15}$ remote storage digital video recorder services highlight the law's persistent focus on copies. In these instances, courts may use findings on the reproduction right to allocate liability for making copyright content available to the public. ${ }^{16}$ In other words, who conducts the act of copying (or on whose facilities the reproduction occurs) determines liability. Where courts refrain from focusing on copying, their interpretation of the making available right (or its national equivalents) may hinge on analogies with outdated technologies or be obscured by vague terms such as 'volition'. ${ }^{17}$ Moreover, the act of hyperlinking to content on the Internet is fundamental to the functioning of the World Wide Web, yet courts are still struggling with the question of whether linking or embedding content located on the Web is an exercise of the right. ${ }^{18}$ These decisions tend to lack transparency and coherence, and as a consequence, the legal landscape is devoid of clear guiding principles to drive the development of the right.

14 See, for example, Melville B Nimmer, 'The Nature of Rights Protected by Copyright' (1962) 10 UCLA Law Review 60, 62 ("As the very name "copyright" suggests, the right to copy represents the most fundamental, as well as historically the first, right in the domain of literary property'). Cf André Lucas in The WIPO Worldwide Symposium on the Future of Copyright and Neighbouring Rights (Le Louvre, Paris, 1-3 June 1994, WIPO Publication No 731 (E), 1994) 279. In the lead-up to the adoption of the Internet Treaties, Lucas reflected that:

$[C]$ opyright and more especially the Anglo-American form of copyright, has evolved around the right of reproduction. How is one therefore to cater to this new reality?. . The truth of the matter, it seems to me, is that the procedures for the distribution of the work no longer appear to be essential.

See also William F Patry, How to Fix Copyright (Oxford University Press, 2011) 12, arguing that 'we must focus on the rules for access as well as on the social, interactive way people now relate to each other and to copyrighted works'.

15 'Cloud' computing has been described, from the perspective of the user, as 'storing and accessing data and programs over the Internet instead of your computer's hard drive': Eric Griffith, 'What Is Cloud Computing?' (13 March 2013) PCMag $<$ http://www.pcmag.com/article2/0,2817,2372163,00.asp>, accessed 11 July 2015.

16 See National Rugby League Investments Pty Ltd v Singtel Optus Pty Ltd (2012) 201 FCR 147.

17 See American Broadcasting Companies, Inc, et al, v Aereo, Inc, $134 \mathrm{~S}$ Ct 2498 (2014); Cartoon Network, LP v CSC Holdings, Inc, 536 F3d 121 (2d Cir 2008) (both decisions applying the public performance right, which gives effect to the making available right in the United States).

18 See, for example, Nils Svensson, Sten Sjögren, Madelaine Sahlman, Pia Gadd $v$ Retriever Sverige AB (Court of Justice of the European Union, Case C-466/12, 13 February 2014) ('Svensson'); Goldman v Breitbart News Network, LLC, 302 F Supp 3d 585 (SDNY 2018). It should be noted that the US case considers the application of the public display right (part of a suite of rights that purportedly give effect to the making available right in the US) to linking. 
Closer analysis of current judicial approaches reveals a number of deficiencies. Although the making available right has two basic elements - (1) an act of making available that is (2) to the public - disproportionate emphasis tends to be placed on the requirement that content be accessible by members of 'the public', with insufficient legal analysis afforded to the 'act' of making available. Furthermore, despite protracted judicial analysis on the meaning of 'the public' (which pre-exists the making available right), its scope remains elusive. The concept of 'the public', developed prior to the proliferation of internet technologies, struggles to keep pace. Pressure on 'the public' as a limit upon the making available right is intensified by our superficial understanding and broad application of the 'act' of making available.

\subsection{A VACUUM OF PRINCIPLES TO GUIDE COPYRIGHT'S DISSEMINATION FUNCTION}

If copyright is to remain relevant in a dynamic communications environment, a clearer path for the making available right must be charted. Reflection on the overall aims of copyright is apt in light of the right's importance to copyright as a whole. We should question whether current approaches to the making available right support the core objectives of copyright, which may be distilled into two main functions: (1) its authorship incentivizing function and (2) its dissemination function. ${ }^{19}$ Securing authors' incentives to create is but one of copyright's fundamental functions; the other end of the 'social contract $^{\prime 20}$ requires that the resulting works be disseminated to the public. Without efficient dissemination of copyright content to the public, the benefits flowing from the copyright system will not be fully realized. Both functions are embedded in modern copyright law's foundational legislation, the Statute of Anne, which for the first time vested copyright in authors and was explicitly titled 'an Act for the encouragement of learning'. ${ }^{21}$

The Internet, in conjunction with communication technologies built upon internet connectivity, has become the primary way in which the public gains exposure to a wide range of content and information. Online dissemination markets ensure that members of the public are able to access, consume and

19 See L Ray Patterson and Stanley F Jr Birch, 'A Unified Theory of Copyright' (2009) 46 Houston Law Review 215, 392, describing dissemination as one of several functions of copyright. 471 .

IceTV Pty Limited v Nine Network Australia Pty Limited (2009) 239 CLR 458

21 The full title of the act was 'An Act for the Encouragement of Learning, by Vesting the Copies of Printed Books in the Authors or Purchasers of such Copies, During the Times therein mentioned': Statute of Anne 1710 (London). 
learn from copyright content. Thus, internet communications hold vast potential for furthering copyright's dissemination function more effectively than ever before. It has been said that the Internet may be the 'ultimate. . . phase in copyright's long trajectory, perfecting the law's early aim of connecting authors to their audiences'. ${ }^{22}$

Decisions on the scope of the making available right have an impact on access markets: they determine whether incumbent disseminators of copyright content maintain control of such markets, or whether they face the threat of 'creative destruction' 23 initiated by technological innovations implemented by rival disseminators. ${ }^{24}$ Stagnant dissemination markets benefit incumbent disseminators; they do not benefit authors and certainly do not benefit the consumers of copyright content. We cannot continue to ignore copyright's dissemination function in decisions on the making available right. If we do so, then a central aspect of copyright is being constructed with an incomplete understanding of copyright's fundamental functions.

In short, the lack of engagement with the making available right at a conceptual level has given us little opportunity to develop coherent principles to guide interpretations of the right. The challenges are particularly acute when courts are faced with new technologies that could initiate the creative destruction of dissemination markets. If we continue with current approaches to the key right in the digital environment, it is unlikely that the aim of perfecting copyright's dissemination function can be achieved.

22 Paul Goldstein, Copyright's Highway: From Gutenberg to the Celestial Jukebox (Stanford Law and Politics, Revised edition, 2003) 277.

${ }_{23}$ See Joseph Schumpeter, Capitalism, Socialism and Democracy (Routledge, 2013) [originally published 1942] 83-84. The notion of 'creative destruction' is discussed further in Chapter 2.

24 Tim $\mathrm{Wu}$ calls for more express consideration of dissemination rivalries under what he describes as copyright's communications policy: Timothy $\mathrm{Wu}$, 'Copyright's Communications Policy' (2004) 103 Michigan Law Review 278 (discussed further in Chapter 2). It is also notable that in 1994, Bernt Hugenholtz predicted a convergence of roles that would ultimately have an impact on dissemination - that is, we would see alliances of 'software or entertainment companies linking up with telecommunications or cable-operators, thus providing right owners with access to and control over multimedia delivery channels': P Bernt Hugenholtz, 'Intellectual Property Rights on the Information Superhighway: Report to the Commission of the European Communities (DG XV)' (August 1994) <https://www.ivir.nl/publicaties/download/1760>, accessed 28 November 2018. 


\subsection{THE OBJECTIVE: A PRINCIPLED FRAMEWORK FOR ANALYSIS}

This book addresses the vacuum of principles and highlights the role of the making available right in furthering copyright's fundamental functions. The principal focus is primary liability for exercising the making available right, as opposed to other doctrines that may apply in certain circumstances to expand or limit the scope of the right. An example is exceptions to infringement (eg, fair use or fair dealing). Such exceptions may operate to circumscribe the scope of the right, but are not considered in detail here, as we should seek to understand the ground for liability before considering the need to exempt certain conduct from infringement. ${ }^{25}$ Likewise, secondary liability principles that extend the scope of liability are not considered in depth. ${ }^{26}$ Again, the rationale is that the primary basis of liability should be fully appreciated before we consider how a third party could be liable for facilitating or encouraging such acts. ${ }^{27}$ In addition, disputes about the exploitation of copyright online

25 It is worth noting that the limits of copyright protection and the public policy objectives of such limits tend to be borne disproportionately by exceptions to copyright infringement. Rights, on the other hand, set the baseline for the protection of rights holders and seem to leave less room for debate: see Ansgar Ohly, 'Economic Rights' in Estelle Derclaye (ed), Research Handbook on the Future of EU Copyright (Edward Elgar Publishing, 2009) 213. See also Hugenholtz, above n 24, arguing that from a systematic perspective, directly curtailing the exclusive right, rather than offsetting the proliferation of exclusive rights by expanding the existing set of limitations and exceptions, 'is more attractive - and certainly more elegant'. Likewise, Pamela Samuelson criticizes efforts to simplify exclusive rights that have effectively led to their expansion: Pamela Samuelson, 'Preliminary Thoughts on Copyright Reform' (2007) 3 Utah Law Review 551, 565. Samuelson argues that:

[t]his manner of articulating exclusive rights implies that if the 1976 Act does not specifically provide an exception for a particular activity that falls within one or more of the broadened exclusive rights, then the activity, no matter how economically trivial, will be deemed illegal unless it can somehow be shoe-horned into the fair use rubric or some other specific exception.

26 The distinction between primary and secondary copyright liability is considered in Chapter 6, but the focus remains on the scope of primary liability. It should be noted that the term 'direct' infringer is used in the US to denote primary infringement. In Australia, on the other hand, authorization liability is categorized as a form of direct infringement (in contrast to indirect infringement involving dealings with infringing copies: see, for example, Copyright Act 1968 (Cth), s 38). For the sake of consistency, this book will use the terms 'primary' and 'secondary' liability to denote the distinction between direct infringement and contributory or vicarious infringement in the US, and primary infringement and authorization liability in Australia.

27 A primary act of infringement must be established before one can proceed to consider secondary infringement: see Roadshow Films Pty Ltd v iiNet Ltd (No 2) (2012) 
often give rise to claims of infringement in relation to a number of rights, not just the making available right. Thus, addressing the multiplicity of overlapping rights is important as online copyright markets develop. ${ }^{28}$ However, we have to understand this key right before we can resolve these overlaps. These are all vital components of copyright, but they do not obviate the need for meaningful engagement with the making available right. ${ }^{29}$

Therefore, this book addresses the inadequacies of existing approaches and discourse regarding the making available right. It exposes the lack of in-depth engagement with the making available right and seeks to fill the resulting vacuum of principles. These steps are traceable through the four parts of the book. Part I starts with the broader context and foundations of copyright law, including its theoretical foundations, and highlights our limited understanding of copyright's dissemination function. Part II turns our focus to the making available right, covering the rationale for its introduction at the international level and its implementation under national legislation or regional directives. The divergent judicial approaches to the right across the three jurisdictions are canvassed and some common themes that nevertheless underlie the different formulations are highlighted. These themes are explored further in Part III, which provides in-depth analysis of the respective elements of the right - that is, 'the public' and the 'act' of making available. In the process, it asks whether internet technologies present an opportunity for the making available right to fulfil copyright's dissemination function more effectively than ever before.

This analysis is brought together in Part IV. It provides the basis for a clearer and more principled approach to the right, by establishing a conceptual framework for understanding the making available right in a dynamic internet environment. This framework for analysis may be utilized by courts, legislators and industry participants to bring transparency and coherence to debates and decisions on the scope of the making available right. In essence, the book iden-

248 CLR 42; Sony Corporation of America v Universal City Studios, Inc, 464 US 417 (1984). Furthermore, secondary infringement is beyond the scope of international treaties and is left to each jurisdiction.

28 It may be that the conventional division of exclusive rights is no longer justified, but whether the making available right is capable of uniting copyright's exclusive rights under one rubric of 'access' remains to be seen. This would depend on how well the making available right matures and develops in a dynamic technological environment. Cf Andrew Christie, 'Simplifying Australian Copyright Law - the Why and the How' (2000) 11 Australian Intellectual Property Journal 40.

29 Opportunities to consider these other copyright issues will no doubt arise before our courts, lawmakers and scholars. This book does not assume the relevance of the principled framework for analysis (laid out in Chapter 7) to these issues, but these principles may nevertheless initiate dialogue on the advancement of copyright's dissemination function using other policy levers within the broader copyright framework. 
tifies and explains the necessary steps for copyright's development in a world where access is the key driver of content dissemination markets. The status quo is unsustainable and we should not insist on maintaining current approaches to the making available right. The framework set out in this book serves to promote transparency and clarity in decisions on the making available right, and explains how we can steer the right in a principled direction. Ultimately, the book exposes the making available right as a beacon for a sustainable copyright system in an environment that prioritizes access. 